\title{
Abundance and community structure of ammonia-oxidizing bacteria and archaea in a temperate forest ecosystem under ten-years elevated $\mathrm{CO}_{2}$
}

\author{
Xien Long ${ }^{\mathrm{a}, \mathrm{c}}$, Chengrong Chen ${ }^{\mathrm{b}, * *}$, Zhihong $\mathrm{Xu}^{\mathrm{c}}$, Ram Oren ${ }^{\mathrm{d}, \mathrm{e}}$, Ji-Zheng $\mathrm{He}^{\mathrm{a}, *}$

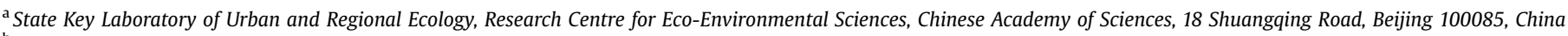 \\ ${ }^{\mathrm{b}}$ Environmental Futures Centre and Griffith School of Environment, Griffith University, Nathan, Queensland 4111, Australia \\ ${ }^{\mathrm{c}}$ Environmental Futures Centre and School of Biomolecular and Physical Sciences, Griffith University, Nathan, Queensland 4111, Australia \\ ${ }^{\mathrm{d}}$ Nicholas School of the Environment and Earth Science, Duke University, Durham, NC 27708, USA \\ e Department of Forest Ecology and Management, Swedish University of Agricultural Sciences (SLU), SE-901 83 Umeå, Sweden
}

\section{A R T I C L E I N F O}

\section{Article history:}

Received 7 August 2011

Received in revised form 12 December 2011

Accepted 13 December 2011

Available online 26 December 2011

\section{Keywords:}

Ammonia-oxidizing bacteria and archaea Elevated $\mathrm{CO}_{2}$

Free air $\mathrm{CO}_{2}$ enrichment (FACE) experiment $\mathrm{N}$ fertilization

Nitrification

Temperate forest ecosystem

\begin{abstract}
A B S T R A C T
Ammonia-oxidizing bacteria (AOB) and archaea (AOA) are considered as the key drivers of global nitrogen $(\mathrm{N})$ biogeochemical cycling. Responses of the associated microorganisms to global changes remain unclear. This study was to determine if there was a shift in soil AOB and AOA abundances and community structures under free-air carbon dioxide $\left(\mathrm{CO}_{2}\right)$ enrichment (FACE) and $\mathrm{N}$ fertilization in Duke Forest of North Carolina, by using DNA-based molecular techniques, i.e., quantitative PCR, restriction fragment length polymorphism (RFLP) and clone library. The $\mathrm{N}$ fertilization alone increased the abundance of bacterial amoA gene, but this effect was not observed under elevated $\mathrm{CO}_{2}$ condition. There was no significant effect of the $\mathrm{N}$ fertilization on the thaumarchaeal amoA gene abundance in the ambient $\mathrm{CO}_{2}$ treatments, while such effect increased significantly under elevated $\mathrm{CO}_{2}$. A total of 690 positive clones for AOA and 607 for AOB were selected for RFLP analysis. Analysis of molecular variance (AMOVA) indicated that effects of $\mathrm{CO}_{2}$ enrichment and $\mathrm{N}$ fertilization on the community structure of $\mathrm{AOA}$ and $\mathrm{AOB}$ were not significant. Canonical correspondence analysis also showed that soil pH rather than elevated $\mathrm{CO}_{2}$ or $\mathrm{N}$ fertilization shaped the distribution of $\mathrm{AOB}$ and $\mathrm{AOA}$ genotypes. A negative linear relationship between the $\delta^{13} \mathrm{C}$ and archaeal amoA gene abundance indicated a positive effect of elevated $\mathrm{CO}_{2}$ on the growth ammonia oxidizing archaea. On the other hand, the community structures of $A O B$ and $A O A$ are determined by the soil niche properties rather than elevated $\mathrm{CO}_{2}$ and $\mathrm{N}$ fertilization.
\end{abstract}

( 2011 Elsevier Ltd. All rights reserved.

\section{Introduction}

Human activities such as the combustion of fossil fuels and deforestation have increased the atmospheric carbon dioxide concentration $\left(\mathrm{CO}_{2}\right)$ by ca. $35 \%$ mostly since the beginning of industrialization. Atmospheric $\mathrm{CO}_{2}$ enrichment has been shown to significantly influence the structure and function of terrestrial ecosystems (Rosenzweig et al., 2007), adding to or interacting with the spatial and temporal effects of environmental variables (Ge et al., 2010). Soil microorganisms, encompassing the greatest diversity in terrestrial ecosystems, are the key drivers in almost all global biogeochemical cycles (Fuhrman, 2009). However, their responses to elevated $\mathrm{CO}_{2}$ are poorly understood (Heimann and Reichstein, 2008) and even controversial (Horz et al., 2004; Schortemeyer et al., 1996).

\footnotetext{
* Corresponding author. Tel.: +86 106284 9788; fax: +86 1062923563.

** Corresponding author. Tel.: +61 73735 7494; fax: +61 737357773 .

E-mail addresses: c.chen@griffith.edu.au (C. Chen), jzhe@rcees.ac.cn (J.-Z. He).
}

Lithoautotrophic ammonia-oxidizing bacteria ( $\mathrm{AOB}$ ), which catalyze the first step of nitrification process $\left(\mathrm{NH}_{3} \rightarrow \mathrm{NO}_{2}^{-}\right)$- a ratelimiting step in the global nitrogen $(\mathrm{N})$ cycle - have been designated as the model for molecular microbial ecology. Evidence is building supporting the presence of ammonia-oxidizing archaea (AOA) in various soil environments (He et al., 2007; Leininger et al., 2006; Nicol and Schleper, 2006). The abundance, distribution and community structure of ammonia-oxidizing organisms can be significantly affected by environmental factors, including levels of ammonium, temperature (Tourna et al., 2008), moisture (Horz et al., 2004), salinity (Bernhard et al., 2010), and pH (He et al., 2007; Nicol et al., 2008). It has been shown that $\mathrm{N}$ fertilization significantly increased the abundance of soil AOB, but not AOA (Di et al., 2009). The effects of elevated $\mathrm{CO}_{2}$ on the abundance of $\mathrm{AOB}$ are less consistent, ranging from no effect in forest ecosystems (O'Neill et al., 1987) or a white clover and perennial ryegrass dominated grassland ecosystem (Schortemeyer et al., 1996) to a decrease in an annual grass and forb dominated grassland ecosystem (Horz et al., 2004). On the other hand, little is known 
regarding effects of elevated $\mathrm{CO}_{2}$ on community structure of $\mathrm{AOB}$ and AOA. Moreover, the interactive effects of multiple factors (i.e., elevated $\mathrm{CO}_{2}$, soil $\mathrm{N}$, temperature and precipitation) on the abundance and community structure of both $\mathrm{AOB}$ and AOA have been scarcely studied. It has been suggested that global changes (e.g., elevated atmospheric $\mathrm{CO}_{2}$ and $\mathrm{N}$ deposition) may change the resource availability (e.g., $\mathrm{C}$ or $\mathrm{N}$ ) and quality, leading to shifts in the abundance and community structure of ammonia oxidizers (Horz et al., 2004).

Previous studies at the Duke free-air $\mathrm{CO}_{2}$ enrichment (FACE) site indicated that both elevated $\mathrm{CO}_{2}$ and $\mathrm{N}$ fertilization altered soil microbial community composition based on phospholipid fatty acid (PLFA) profiling (Feng et al., 2010), whereas another study suggested that the bacterial community composition was more influenced by spatial variations than the $\mathrm{CO}_{2}$ enrichment ( $\mathrm{Ge}$ et al., 2010). Increased allocation of $C$ (carbohydrates) into the soil under elevated $\mathrm{CO}_{2}$ (Palmroth et al., 2006) and enhanced soil $\mathrm{N}$ availability with $\mathrm{N}$ fertilization have led to the shifts in the abundance and composition of soil microbial communities (Finzi et al., 2006). Reports on the responses of $\mathrm{AOB}$ to elevated $\mathrm{CO}_{2}$ are controversial in the literature. Some studies found that elevated $\mathrm{CO}_{2}$ did not affect AOB abundance or nitrifying enzyme activity (Barnard et al., 2004; O'Neill et al., 1987; Schortemeyer et al., 1996), whereas others revealed that elevated $\mathrm{CO}_{2}$ decreased the abundance of $\mathrm{AOB}$ in the grassland ecosystem, and this effect was enhanced under elevated precipitation (Horz et al., 2004). In this study, we examined the separate and combined effects of $\mathrm{CO}_{2}$ enrichment (for ten-years) and $\mathrm{N}$ fertilization (for two years) on the abundance and community structure of soil AOB and AOA in a temperate forest, North Carolina, USA. It was hypothesized that: (1) whether both the abundance of $\mathrm{AOA}$ and $\mathrm{AOB}$ will increase under elevated $\mathrm{CO}_{2}$ or $\mathrm{N}$ fertilization? And (2) whether the community structures of AOB and $\mathrm{AOA}$ will shift under long-term elevated $\mathrm{CO}_{2}$ ?

\section{Materials and methods}

\subsection{Site description and soil sampling}

The FACE experiment was established in the Duke Forest (Orange County, North Carolina, USA) $\left(35^{\circ} 58^{\prime} 41^{\prime \prime} \mathrm{N}, 79^{\circ} 05^{\prime} 39^{\prime \prime} \mathrm{W}\right)$. The site has a temperate climate with a mean annual temperature of $15.5^{\circ} \mathrm{C}$ and average annual precipitation of $1140 \mathrm{~mm}$ (Oren et al., 2001). Duke Forest is dominated by loblolly pine (Pinus taeda L.) stand established in 1983. Six of the eight $30 \mathrm{~m}$ diameter circular plots were utilized in this study. Three experimental plots were fumigated with $\mathrm{CO}_{2}$ to maintain the atmospheric $\mathrm{CO}_{2}$ concentration of $200 \mu \mathrm{L} \mathrm{L}^{-1}$ above the ambient (i.e., $\sim 565 \mu \mathrm{LCO}_{2} \mathrm{~L}^{-1}$ at the year of soil sampling), while three control plots were fumigated with ambient air only $\left(365 \mu \mathrm{L} \mathrm{CO}_{2} \mathrm{~L}^{-1}\right)$. The plots $(n=6)$ were arranged in a complete block design to lessen topographic variation and potential fertility gradients. The $\mathrm{CO}_{2}$ enrichment experiment began on 27th August 1996 (Oren et al., 2001). For the N amendment study, each plot was split into two halves inserting an impermeable layer through the root zone $(0.7 \mathrm{~m})$ with one-half of each plot fertilized at a rate of $11.2 \mathrm{~g} \mathrm{~N} \mathrm{~m}^{-2} \mathrm{yr}^{-1}$ and the other half unfertilized (Oren et al., 2001). For $\mathrm{N}$ fertilization, ammonium-nitrate pellets were applied in two half-doses in March and April of 2005, and applied in a single full-dose annually in March in the following years. Thus, four treatments were designated as $\mathrm{A}$ and $\mathrm{E}$ for ambient and elevated $\mathrm{CO}_{2}$, and $\mathrm{U}$ and $\mathrm{N}$ for unfertilized and $\mathrm{N}$-fertilized, respectively, resulting in 4 treatments: $\mathrm{AU}, \mathrm{EU}, \mathrm{AN}$ and EN.

Soils at the site are classified as the Enon series, a low-fertility, slightly acidic, Ultic Alfisol ( $\left.\mathrm{pH} 5.75,0.1 \mathrm{~mol} \mathrm{~L}^{-1} \mathrm{CaCl}_{2}\right)$. For each treatment, 5 sub-samples of the topsoil $(0-10 \mathrm{~cm})$ were collected and mixed to form one composite sample in August 2006. The sampling was conducted at $c a$. 1.5 years after inserting the impermeable layers and fertilization. Samples were taken along the central section of the half plot to avoid the disturbance of impermeable layers. Each composite sample was placed in a sterile plastic bag, sealed and kept on ice several hours before transporting to Australia by dry ice. All samples were passed through a $2.0-\mathrm{mm}$ sieve and subsamples were stored at $-80{ }^{\circ} \mathrm{C}$ for DNA analysis. Further details regarding FACE technology and site characteristics can be found in the previous publication (Oren et al., 2001).

\subsection{Soil DNA extraction and $P C R$}

Triplicate soil DNA of each treatment was extracted from $0.3 \mathrm{~g}$ of defrosted soil sample using the MoBio Powersoil DNA Isolation Kit (Carlsbad, USA) according to the manufacturer's instruction. The process of soil DNA extraction was under the uniform conditions like the same temperature, chemical reagents and the handler. The extracted DNA was high quality with ratios of A260/A230 and A260/A280 above 1.5 and 1.8, respectively (He et al., 2005). The extracted DNA was stored at $-20^{\circ} \mathrm{C}$. The effect of soil inhibitors on PCR was tested in a dilution series of 10,20 and 50-fold of the extracted DNA in the presence and absence of bovine serum albumin (BSA). It was found that a 10 -fold dilution was enough to remove the effect of soil inhibitors on qPCR. The amoA genes of AOA and AOB were amplified using primers amoA1F (GGG GTT TCT ACT GGT GGT)/amoA2R (CCC CTC KGS AAA GCC TTC TTC) and CrenamoA23F (ATG GTC TGG CTW AGA CG)/CrenamoA616R (GCC ATC CAT CTG TAT GTC CA), respectively, as described previously (He et al., 2007; Tourna et al., 2008). The $50 \mu \mathrm{l}$ reaction mixture contained: $10 \mu \mathrm{L} 5 \times$ GoTaq Flexi Green Buffer (Promega), $2.5 \mathrm{mM}$ $\mathrm{MgCl}_{2}, 750 \mu \mathrm{M}$ each dNTP, $100 \mu \mathrm{M}$ each primer, 1.25 units GoTaq DNA polymerase (Promega), $0.5 \mu \mathrm{L}$ template DNA and ultraclean water to volume.

\subsection{Establishment of $A O B$ and $A O A$ amoA gene fragment libraries and identification of associated genotypes}

The obtained PCR products were purified using a QIAquick Gel Extraction Kit (Qiagen, Valencia, CA). Clone libraries were constructed using the pGEM $^{\circledR}$-T Easy Vector System and JM109 Competent Cells (Promega, Madison, WI) following manufacturer's instruction. Twelve bacterial $a m o A$ gene clone libraries and the same number of thaumarchaeal $a m o A$ gene clone libraries were established. Approximately 60 white clones were randomly picked up for checking with $\mathrm{T} 7 / \mathrm{Sp} 6$ primers. The amoA genotypes were identified using the restriction fragment length polymorphism (RFLP). The positive clones of AOA were digested with MboI (NEB) and HaeIII (NEB) and $\mathrm{AOB}$ with $\mathrm{MboI}(\mathrm{NEB})$, and $5 \mu \mathrm{L}$ of restriction digest fragments were loaded on a $3 \%$ agarose gel, running at $100 \mathrm{~V}$ in $1 \times$ TAE buffer for $60 \mathrm{~min}$ and digitally photographed using ChemiDocTM XRS imaging system (Bio-Rad). The amoA gene patterns were checked using the Quantity-One software (Bio-Rad). Triplicate of each representative genotypes from the clone libraries were selected for sequencing (3130x1 Genetic Analyzer, Applied Biosystems). The obtained representative sequences were submitted to GenBank under accession numbers HM131547-HM131578.

\subsection{Quantitative PCR analyses of total bacterial and archaeal rRNA and amoA genes}

Quantitative PCR was performed on a Mastercycler thermocycler (Eppendorf). The plasmid was extracted using QIAprep Spin Miniprep Kit (QIAGEN) and DNA concentration determined using a NanoDrop 2000 UV-Vis Spectrophotometer (Thermo Scientific). 
Standardization templates were performed with a dilution series $\left(10^{-1}-10^{-8}\right.$ times) of the environmental sample plasmids with EASY Dilution (for Real Time PCR) (Takara). The reaction was performed in a $20 \mu \mathrm{L}$ volume containing $10 \mu \mathrm{L} \mathrm{SYBR}^{\circledR}$ Premix Ex Taq ${ }^{\mathrm{TM}}$ (Perfect Real Time) (Takara Bio), $200 \mu \mathrm{M}$ of each primer and $2 \mu \mathrm{L}$ of template DNA solution. Universal primer sets $338 \mathrm{f}$ (ACT CCT ACG GGA GGC AG)/518r (ATT ACC GCG GCT GCT GG) and A109f (ACK GCT CAG TAA CAC GT)/A334r (TCG CGC CTG CTG CTC CCC GT) were used to determine population size of total bacteria and archaea, respectively (Sun et al., 2009). The thermal cycling conditions for the bacterial 16s rRNA gene was as follows: an initial denaturation step at $95^{\circ} \mathrm{C}$ for $2 \mathrm{~min} ; 40$ cycles of $95^{\circ} \mathrm{C}$ for $20 \mathrm{~s}, 55^{\circ} \mathrm{C}$ for $15 \mathrm{~s}$, $72{ }^{\circ} \mathrm{C}$ for $30 \mathrm{~s}, 80^{\circ} \mathrm{C}$ for $20 \mathrm{~s}$; final extension at $72{ }^{\circ} \mathrm{C}$ for $60 \mathrm{~s}$, followed by a melting curve cycle. For archaeal $16 \mathrm{~S}$ rRNA gene, only annealing temperature was changed to $57^{\circ} \mathrm{C}$. The primer pairs for quantitative analysis of $a m o A$ genes were described as above. The thermal cycling conditions for the thaumarchaeal amoA (AOA) gene were as follows: an initial denaturation step at $95^{\circ} \mathrm{C}$ for $2 \mathrm{~min} ; 40$ cycles of $95{ }^{\circ} \mathrm{C}$ for $15 \mathrm{~s}, 55^{\circ} \mathrm{C}$ for $30 \mathrm{~s}, 72^{\circ} \mathrm{C}$ for $45 \mathrm{~s}, 80^{\circ} \mathrm{C}$ for $20 \mathrm{~s}$; final extension at $72{ }^{\circ} \mathrm{C}$ for $60 \mathrm{~s}$, followed by a melting curve analysis. The fluorescence intensity was detected at $80{ }^{\circ} \mathrm{C}$. The thermal protocol for AOB was the same with AOA except the annealing temperature of $53{ }^{\circ} \mathrm{C}$. Quantitative PCR was performed on purified template plasmid DNA to make a standard curve with a $\log$-linear effect of target concentration $\left(r^{2}=0.999\right)$ and an amplification efficiency of 0.950 .

\subsection{Statistical and phylogenetic analysis}

Univariate statistical analyses were performed using Sigmaplot 11(Systat Software, Inc., San Jose, CA). The abundance data were analyzed by analysis of variance (ANOVA) using split-plot model and generalized linear model (GLM). The RFLP genotypes of different treatments were analyzed using an AMOVA executed in Arlequin 3.5 (Excoffier and Lischer, 2010; He et al., 2006). Canonical correspondence analysis (CCA) was performed using the community ecology package "vegan" (Oksanen et al., 2010). Three important explanatory variables $\left(\mathrm{pH}, \mathrm{NH}_{4}^{+}-\mathrm{N}\right.$ and dissolved organic $C(D O C) /$ dissolved organic $N$ (DON) ratio) were selected for the CCA ordination diagrams by 1000 times permutation test. $P$-values $\leq 0.05$ were considered significant. The Neighbor-joining method was followed to construct the phylogenetic tree using MEGA5 (Kumar et al., 2008) and based on the maximum composite likelihood model for calculating the evolutionary distance.

\section{Results}

\subsection{Abundances of soil bacteria and archaea}

Soil bacterial 16S rRNA gene abundance ranged from $0.49 \times 10^{9}$ to $2.45 \times 10^{9}$ copies $g^{-1}$ dry soil weight (Fig. $1 \mathrm{a}$ ). These values were significantly higher than those of archaeal 16S rRNA genes $\left(1.32 \times 10^{6}-6.61 \times 10^{6}\right.$ copies $g^{-1}$ dry soil weight) (Fig. $\left.1 \mathrm{a}\right)$ $(p<0.01)$. Bacterial abundance reflected an interactive effect of $\mathrm{CO}_{2}$ enrichment and $\mathrm{N}$ fertilization $(p=0.024)$, indicating that the $\mathrm{N}$ effect was restricted to ambient $\mathrm{CO}_{2}$ conditions only ( $\mathrm{AU}>\mathrm{AN}$; no difference between ambient and elevated $\mathrm{CO}_{2}$ conditions). In contrast, no significant differences or interaction effect $(p>0.05)$ were detected in the archaeal 16S rRNA genes abundance among the treatments (Fig. 1a). There were a negative relationship between the abundance of the bacterial or archaeal 16S rRNA gene and the ratio of DOC to DON and a negative relationship between the archaeal 16S rRNA gene abundance and $\delta^{13} \mathrm{C}$ value of the soil organic carbon $(p<0.05)$ (Table 2$)$.
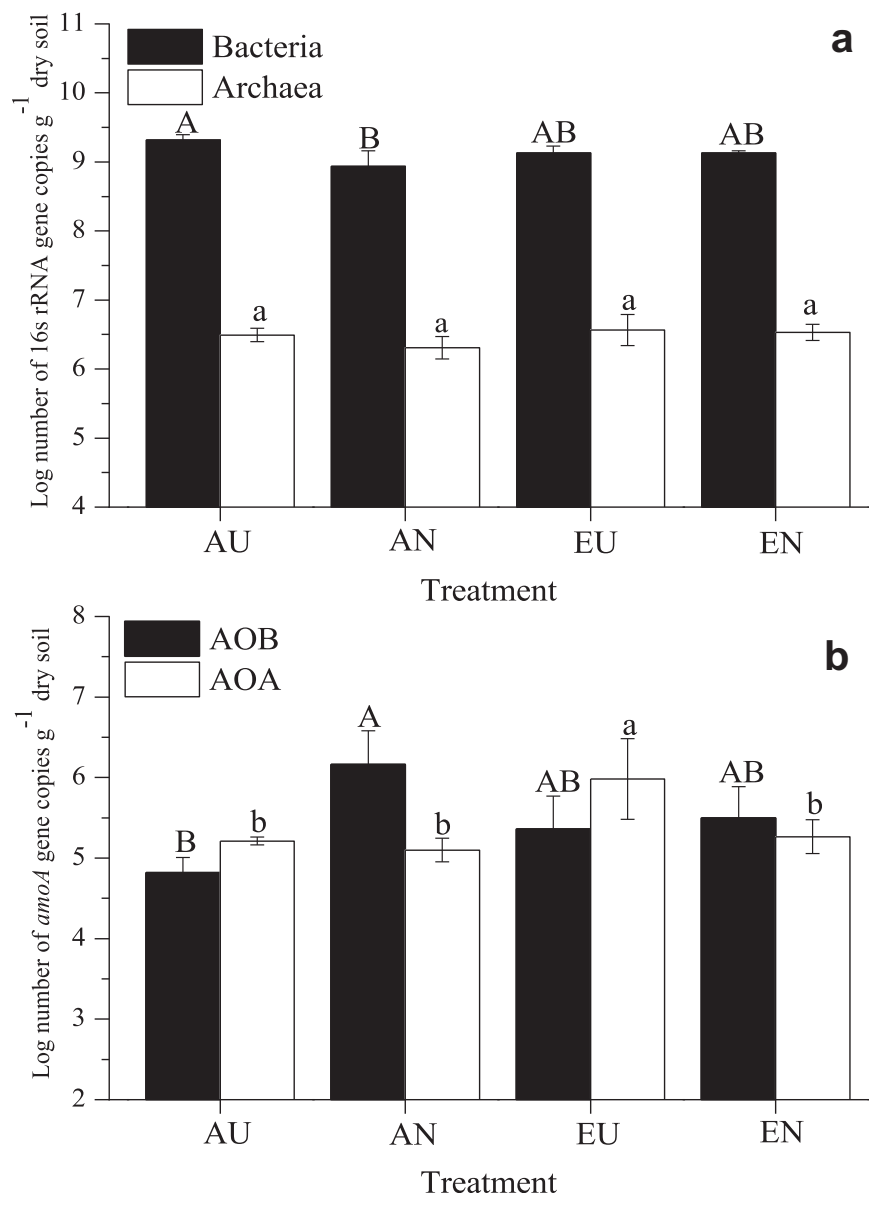

Fig. 1. Bacterial and archaeal $16 \mathrm{~S}$ rRNA gene copy numbers under different treatments (a) and ammonia-oxidizing bacteria (AOB) and ammonia-oxidizing archaea (AOA) amoA gene copy numbers under different treatments (b). Abbreviations: $\mathrm{AU}$, ambient $\mathrm{CO}_{2}$ and unfertilized; $\mathrm{AN}$, ambient $\mathrm{CO}_{2}$ and fertilized; EU, elevated $\mathrm{CO}_{2}$ and unfertilized; and EN, elevated $\mathrm{CO}_{2}$ and fertilized.

\subsection{Abundances of soil $A O B$ and $A O A$}

Bacterial amoA genes abundance ranged between $0.05 \times 10^{6}$ and $3.72 \times 10^{6}$ copies $\mathrm{g}^{-1}$ dry soil weight across all the treatments, similar to the number of thaumarchaeal amo $A$ genes $\left(0.09 \times 10^{6}-1.86 \times 10^{6}\right.$ copies $g^{-1}$ dry soil weight; Fig. $\left.1 \mathrm{~b}\right)$. There was a significant interactive effect between $\mathrm{N}$ fertilization and $\mathrm{CO}_{2}$ enrichment on the AOB abundance $(p=0.022)$. This effect was manifested in a similar number of the bacterial amoA gene copies under elevated $\mathrm{CO}_{2}$ at both $\mathrm{N}$ levels (i.e., $\mathrm{EU}=\mathrm{EN}$ ) but higher number under ambient $\mathrm{CO}_{2}$ conditions with $\mathrm{N}$ fertilization than under native soil $\mathrm{N}$ condition (i.e., $\mathrm{AU}<\mathrm{AN}$, with the elevated treatments not different from either of the ambient treatments; Fig. 1b). There was also a significant $\mathrm{CO}_{2} \times \mathrm{N}$ effect on the number of thaumarchaeal amoA gene copies $(p=0.031)$, but the effect was limited to a $\mathrm{CO}_{2}$-induced increase in the number under native soil $\mathrm{N}$ only (i.e., $\mathrm{EU}>\mathrm{EN}=\mathrm{AU}=\mathrm{AN}$; Fig. $1 \mathrm{~b}$ ). In the unfertilized treatments with either ambient or elevated $\mathrm{CO}_{2}$ (i.e., $\mathrm{AU}$ and $\mathrm{EU}$ ), $\mathrm{AOA}$ have more copy numbers of amoA gene than $\mathrm{AOB}$ with the mean ratios of 2.3 and 4.1 respectively. In contrast, there was more $A O B$ of the amoA gene than AOA under $\mathrm{N}$ fertilization in both ambient and elevated $\mathrm{CO}_{2}$ (i.e., $\mathrm{AN}$ and $\mathrm{EN}$ ), with mean ratios of 2 and 10 , respectively. Linear regression analysis indicated a negative relationship between the archaeal amoA gene abundance and the $\delta^{13} \mathrm{C}(p<0.05)$. 


\subsection{Community and phylogenetic analysis of $A O B$ and $A O A$}

The community structure of $\mathrm{AOB}$ and $\mathrm{AOA}$ was analyzed via clone library followed by RFLP (Table 3 ). Three duplicates of unique genotypes were selected from each library for sequencing (in total 99 and 59 sequences of $\mathrm{AOA}$ and $\mathrm{AOB}$, respectively). In this study, amo $A$ gene sequences that shared $\geq 97 \%$ similarity were defined as one genotype or operational taxonomic unit (OTU). Phylogenetic trees of the bacterial and thaumarchaeal amoA gene sequences and related GenBank sequences are shown in Figs. 2 and 3. For bacterial amoA genes, clusters 1, 2 and 9 were detected across all treatments with cluster 2 dominated. However, cluster $3 a$ and cluster 11 were only observed under elevated $\mathrm{CO}_{2}$ conditions (i.e., EU, EN, Fig. 2, Table 3). On the other hand, all thaumarchaeal amoA genes of different treatments fell within two clusters, designated as soil cluster 2 and soil cluster 5 . Thaumarchaeal amoA sequences affiliated with soil cluster 2 were retrieved from various soils (He et al., 2007; Leininger et al., 2006), while most sequences of soil cluster 5 came from water column or marine. There were no significant shifts of amoA genotypes determined by RFLP in the AU, AN, EU and EN treatments and between soil cluster 2 and soil cluster 5 , although soil cluster 5 predominated in all the treatments (Table 3 ).

\subsection{Communities of $A O B$ and $A O A$ in response to environmental factors}

Three important environmental variables $\left(\mathrm{NH}_{4}^{+}-\mathrm{N}, \mathrm{pH}\right.$ and DOC/DON ratio) and dominant amoA gene RFLP genotypes were included in the canonical correspondence analysis (Table 1). The first two axes of the CCA of the AOB communities versus environmental factors explained $47.8 \%$ of the total variance in the amoA genotypes composition and $97.7 \%$ of the cumulative variance of the genotype-environment relationship (Fig. 4a). The DOC/DON ratio ( $F=2.573, p=0.045,1000$ permutations) was the most influential environmental gradient on the distribution of amoA genotype of $\mathrm{AOB}$ among the samples, followed by $\mathrm{pH}$ value $(F=2.167, p=0.084)$ and $\mathrm{NH}_{4}^{+}-\mathrm{N}$ concentration $(F=1.949$, $p=0.118$ ). However, only $31.0 \%$ of the total variance and $83.2 \%$ of the cumulative variance of the AOA communities versus environmental variables were explained by the first two axes of the CCA (Fig. 4b). The CCA showed that only soil pH significantly affected the distribution of the AOA amoA genotypes $(F=2.036, p=0.028,1000$ permutations).

\subsection{Analyses of molecular variance of amoA gene sequences}

The sequences of unique RFLP patterns and their statistical numbers of selected positive clones were used to analyse the molecular variance of $a m o A$ gene among different treatments. The AMOVA results showed that the variance $(3.1 \%)$ of AOA amoA gene within the replicates was higher than the variance $(0.59 \%)$ among the treatments. A small value for the overall fixation index $\left(F_{S C}\right)$ was identical to the $F_{\mathrm{ST}}$ measure of the genetic distance among the samples. Those parameters were not significantly different from zero and, hence, revealed genetic homogeneity in the AU, AN, EU and EN treatments (Table 4). In this study, we obtained negative variance components of $\mathrm{AOB}$ amoA gene among the treatments. The variance components and $F_{\mathrm{ST}}$ evaluation of AMOVA are based on a multi-allelic model (Excoffier and Lischer, 2010), which relies on estimates of relationships between alleles in the same populations

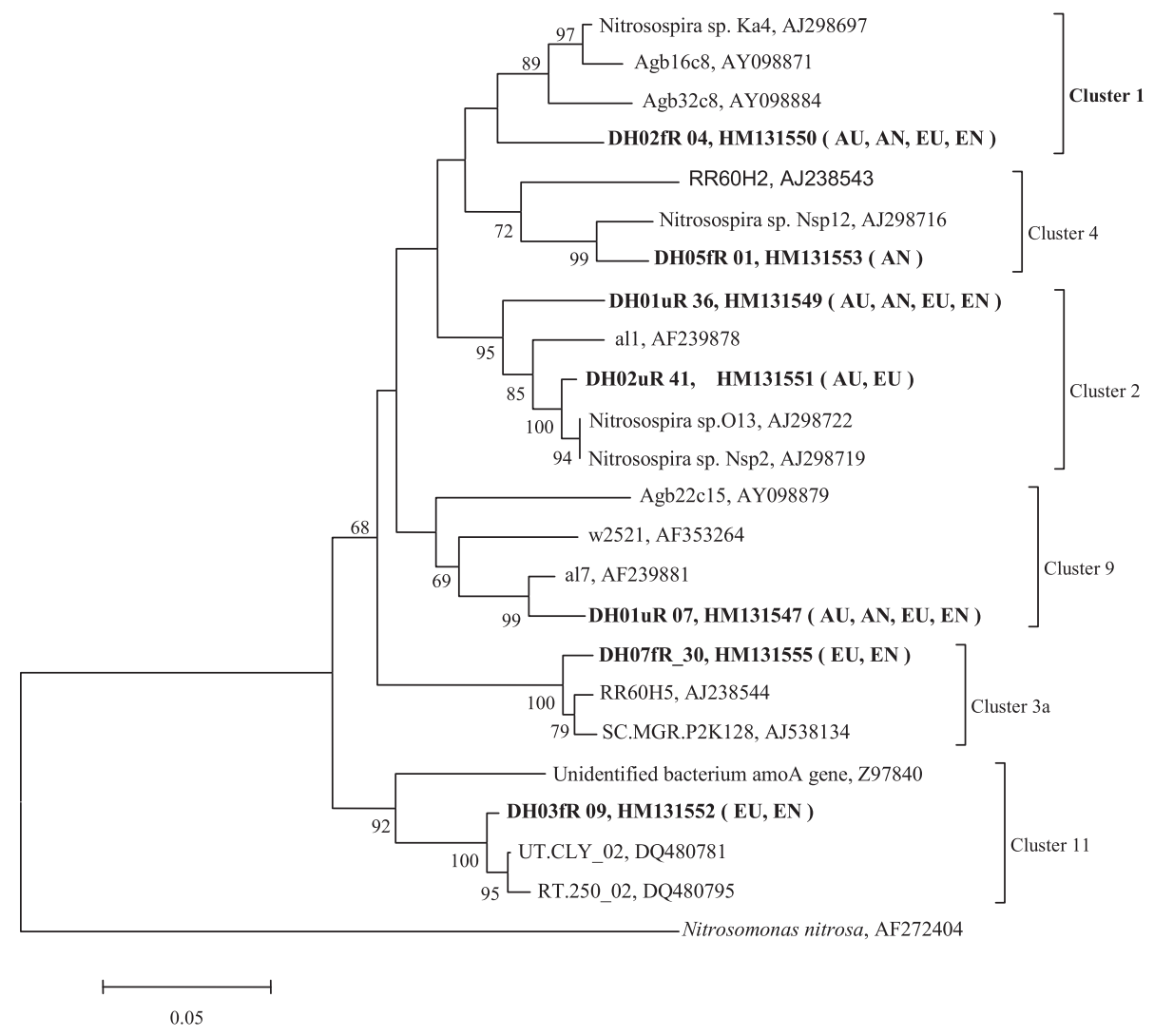

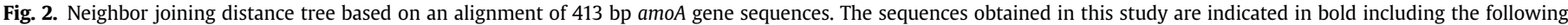

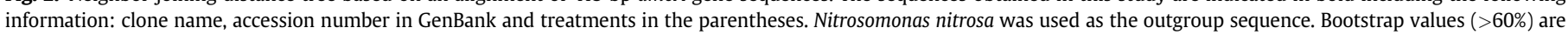
indicated at branch points. The scale bar represents $5 \%$ sequence divergence. 


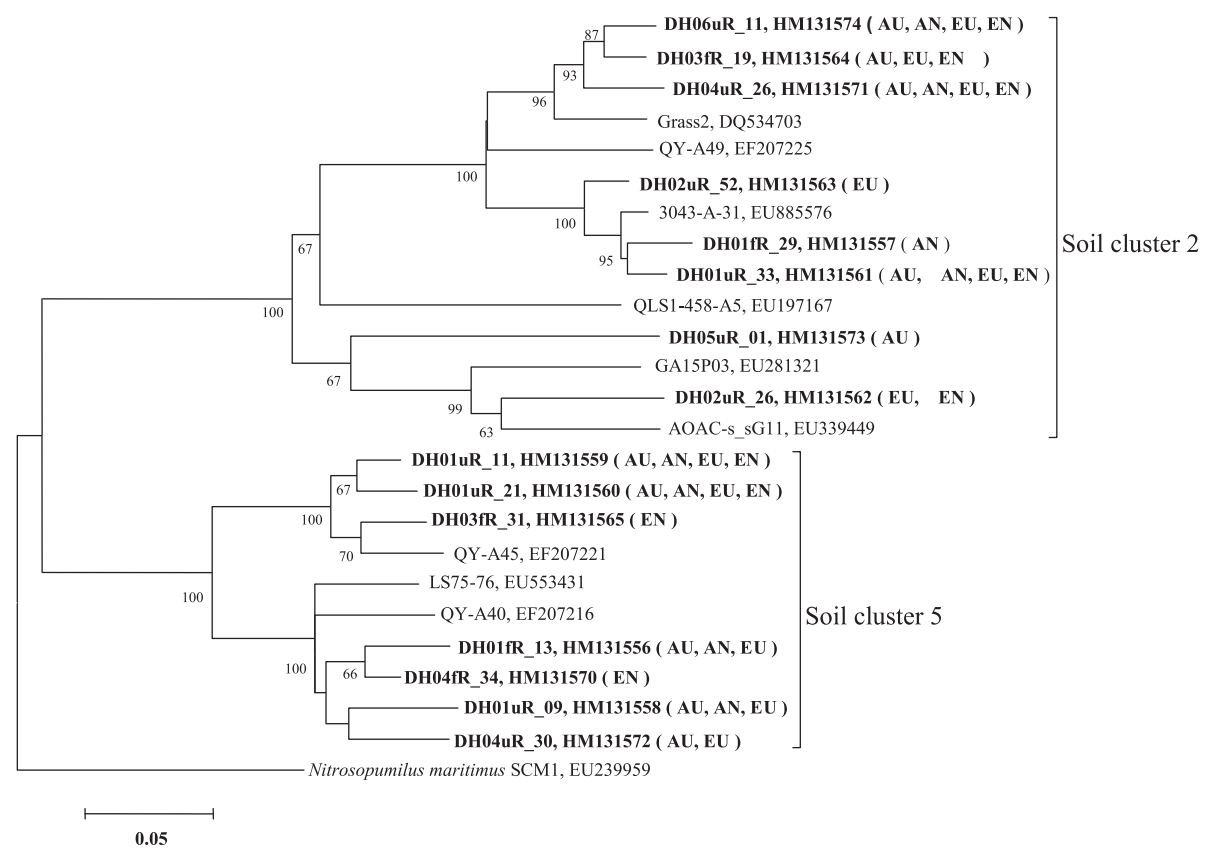

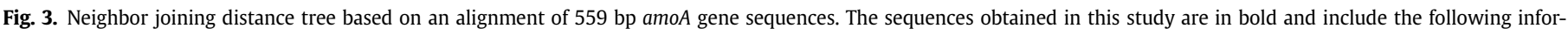

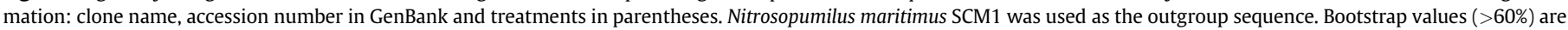
indicated at branch points. The scale bar represents $5 \%$ sequence divergence.

relative to the alleles of different populations. Usually, negative variance components are produced only if the estimated parameter value is close to zero, in another word, without a genetic structure among the treatments.

\section{Discussion}

\subsection{Responses of soil bacterial and archaeal abundance to elevated $\mathrm{CO}_{2}$ and $\mathrm{N}$ fertilization}

Our results indicated that a 10 -year elevated $\mathrm{CO}_{2}$ exposure negated the $\mathrm{N}$-induced reduction of soil bacterial abundance, which suggests that the negative effect of $\mathrm{N}$ fertilization (and perhaps $\mathrm{N}$ deposition) on the bacterial abundance decreases with increasing atmospheric $\mathrm{CO}_{2}$ concentration. However, elevated $\mathrm{CO}_{2}$ or $\mathrm{N}$ fertilization did not significantly affect the abundance of soil archaea. Previous studies also found that in comparison with fallow or without fertilizers' treatment, a range from 1.48 to 2.44 -fold decrease of bacterial abundance was detected under long-term $\mathrm{N}$ fertilization in a wheat-maize rotation system and a wheat continuous cropping system (He et al., 2007; Shen et al., 2010). Moreover, effects of long-term fertilization on specific bacterial and archaeal taxa revealed that ammonia sulphate significantly decreased the abundance of bacteria, archaea and most of the specific taxa, except for Acidobacteria (Wessén et al., 2010). In this study, we observed a 2.03-fold decrease of bacterial abundance with 2 years of $\mathrm{N}$ fertilization. Due to only two years' $\mathrm{N}$ fertilization addition and the possible bias of DNA PCR-based approaches, the changes in bacterial abundance among the treatments were not great enough to be explained by the fertilizer effect. Wallenstein et al. (2006) speculated that shifts of soil $\mathrm{C} / \mathrm{N}$ ratio and $\mathrm{pH}$ value induced by $\mathrm{N}$ saturation decreased bacterial biomass under longterm fertilization in three forest ecosystems. Our results indicated that ratio of DOC to DON negatively influenced the abundance of bacteria and archaea (Table 2). However, effects of elevated $\mathrm{CO}_{2}$ on soil bacterial and archaeal abundance were not widely covered. Natural $\mathrm{CO}_{2}$ vent has been reported to decrease the abundance of soil bacteria and archaea under grass species (Oppermann et al., 2010). Yet, a four-year exposure to $\mathrm{CO}_{2}$ in a FACE experiment site decreased the abundance of archaea but did not affect the

Table 1

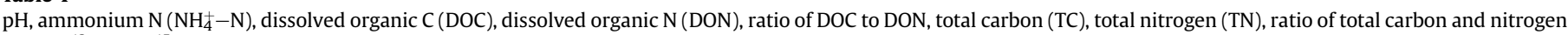
$(\mathrm{C} / \mathrm{N}), \delta^{13} \mathrm{C}$ and $\delta^{15} \mathrm{~N}$ of the soil samples from the Duke forest plots.

\begin{tabular}{|c|c|c|c|c|c|c|c|c|c|c|}
\hline Treatment & $\begin{array}{l}\mathrm{pH} \\
\left(\mathrm{H}_{2} \mathrm{O}\right)\end{array}$ & $\begin{array}{l}\mathrm{NH}_{4}^{+}-\mathrm{N} \\
\left(\mathrm{mg} \mathrm{kg}^{-1}\right)\end{array}$ & $\begin{array}{l}\mathrm{DOC} \\
\left(\mathrm{mg} \mathrm{kg}^{-1}\right)\end{array}$ & $\begin{array}{l}\text { DON } \\
\left(\mathrm{mg} \mathrm{kg}^{-1}\right)\end{array}$ & $\mathrm{DOC} / \mathrm{DON}$ & TC (\%) & $\mathrm{TN}(\%)$ & $\mathrm{C} / \mathrm{N}$ & $\delta^{13} \mathrm{C}(\%)$ & $\delta^{15} \mathrm{~N}(\%$ \\
\hline AU (plot_1) & 4.94 & 189.37 & 447.72 & 75.45 & 5.93 & 6.16 & 0.23 & 26.78 & -28.72 & 31.12 \\
\hline AU (plot_5) & 5.00 & 178.84 & 857.90 & 98.80 & 8.68 & 3.87 & 0.19 & 20.37 & -28.51 & 14.79 \\
\hline AU (plot_6) & 4.61 & 187.90 & 912.88 & 93.67 & 9.75 & 7.64 & 0.30 & 25.47 & -27.79 & 20.98 \\
\hline AN (plot_1) & 5.20 & 216.33 & 445.73 & 90.61 & 4.92 & 4.31 & 0.18 & 23.94 & -28.33 & 20.74 \\
\hline AN (plot_5) & 4.69 & 266.11 & 1233.65 & 95.14 & 12.97 & 6.27 & 0.30 & 20.90 & -27.80 & 15.35 \\
\hline AN (plot_6) & 4.12 & 191.93 & 880.96 & 78.74 & 11.19 & 5.84 & 0.24 & 24.33 & -27.54 & 13.26 \\
\hline EU (plot_2) & 4.62 & 111.13 & 459.08 & 57.59 & 7.97 & 5.90 & 0.18 & 32.78 & -34.56 & 21.68 \\
\hline EU (plot_3) & 4.14 & 207.56 & 664.23 & 86.98 & 7.64 & 7.42 & 0.31 & 23.94 & -33.84 & 13.59 \\
\hline EU (plot_4) & 5.06 & 255.26 & 661.67 & 91.62 & 7.22 & 7.15 & 0.32 & 22.34 & -33.99 & 20.22 \\
\hline EN (plot_2) & 4.72 & 139.01 & 723.50 & 85.62 & 8.45 & 4.80 & 0.19 & 25.26 & -35.35 & 17.76 \\
\hline EN (plot_3) & 4.69 & 194.39 & 628.85 & 72.79 & 8.64 & 5.23 & 0.26 & 20.12 & -34.76 & 8.72 \\
\hline EN (plot_4) & 4.44 & 148.22 & 845.94 & 88.92 & 9.51 & 7.13 & 0.26 & 27.42 & -32.67 & 16.02 \\
\hline
\end{tabular}

A: Ambient $\mathrm{CO}_{2}$; E: Elevated $\mathrm{CO}_{2}$; U: Unfertilized; and N: Fertilized. 
Table 2

Pearson's correlations $(r)$ between soil properties and community size (qAOB, qAOA qBacteria and qArchaea) measured at each individual sampling point $(n=12)$.

\begin{tabular}{lcccc}
\hline & qAOB & qAOA & qBacteria & qArchaea \\
\hline $\mathrm{pH}$ & 0.19 & -0.26 & 0.39 & 0.05 \\
$\mathrm{NH}_{4}^{+}-\mathrm{N}$ & 0.45 & -0.34 & -0.16 & -0.34 \\
$\mathrm{DOC}$ & 0.19 & $-0.54^{*}$ & -0.39 & $-0.52^{*}$ \\
$\mathrm{DON}$ & 0.14 & $-0.56^{*}$ & 0.21 & -0.04 \\
$\mathrm{DOC} / \mathrm{DON}$ & 0.16 & -0.37 & $-0.59^{* *}$ & $-0.60^{* *}$ \\
$\mathrm{TC}$ & 0.31 & 0.13 & -0.10 & -0.08 \\
$\mathrm{TN}$ & 0.39 & -0.09 & -0.14 & -0.13 \\
$\mathrm{C} / \mathrm{N}$ & -0.04 & 0.43 & -0.04 & 0.03 \\
$\delta^{13} \mathrm{C}$ & -0.26 & $-0.60^{* *}$ & 0.08 & $-0.58^{* *}$ \\
$\delta^{15} \mathrm{~N}$ & -0.03 & -0.01 & 0.47 & -0.03 \\
\hline
\end{tabular}

Abbreviations: DOC, dissolved organic carbon; DON, dissolved organic nitrogen; TC, total carbon; TN, total nitrogen; AOB, ammonia-oxidizing bacteria; AOA, ammoniaoxidizing archaea. Values labeled with ${ }^{* *}$ and ${ }^{*}$ are statistically significant at $p<0.05$ and $p<0.10$, respectively.

population size of soil bacteria under trembling aspen (Lesaulnier et al., 2008). It was believed that elevated $\mathrm{CO}_{2}$ increased plant photosynthetic rate and productivity, and the increase in the above-ground photosynthesis will result in greater below-ground $C$ allocation via root exudation and rhizodeposition (Hungate et al., 1997; Jackson et al., 2009; Palmroth et al., 2006; Phillips et al., 2006), which can directly stimulate changes in the size and community structure of soil microorganisms (Drigo et al., 2009). However, no significant difference in DOC between ambient $\mathrm{CO}_{2}$ and elevated $\mathrm{CO}_{2}$ was observed in this study which was partly in consistent with the study of Jackson et al. (2009), who found that no significant change of DOC between ambient and elevated $\mathrm{CO}_{2}$ condition in the $\mathrm{O}$ horizon of soil. Moreover, a significant difference of $\delta^{13} \mathrm{C}$ between ambient $\mathrm{CO}_{2}$ and elevated $\mathrm{CO}_{2}$ indicated an increase in plant photosynthetic rate, which could supply greater below-ground labile carbon (Table 1). No differences of DOC among treatments can be explained by the soil respiration increase under elevated $\mathrm{CO}_{2}$ (Luo and Zhou, 2006).

\subsection{Responses of $A O B$ and $A O A$ abundance to elevated $\mathrm{CO}_{2}$ and $N$ fertilization}

Quantitative PCR data show a positive effect of the $\mathrm{N}$ addition on $A O B$ but no significant effect on AOA under ambient $\mathrm{CO}_{2}$. Studies on the effect of $\mathrm{N}$ addition have shown an increasing in amoA gene abundance of soil AOB but not of AOA, with AOB being predominant over AOA in the N-rich environment (Di et al., 2009; Hallin et al., 2009). Progressive nutrient limitation (particularly N) induced by inputs of $\mathrm{C}$ resulting from enhanced photosynthesis under elevated $\mathrm{CO}_{2}$ was the main cause of shifts in the abundance and community structure of soil microorganisms (Hungate et al., 1999; Oren et al., 2001; Schaeffer et al., 2007). However, a study on the Duke FACE site revealed that the carbon fixation faster than nitrogen in tree biomass under elevated $\mathrm{CO}_{2}$ would delay the progressive $\mathrm{N}$ limitation (Finzi et al., 2006). In the present study, the effect of $\mathrm{N}$ fertilization was different under elevated $\mathrm{CO}_{2}$; this phenomenon had been discussed by Zak et al. (2000), who thought that the effect of $\mathrm{N}$ fertilization on microbial communities under elevated $\mathrm{CO}_{2}$ depended on the plant species presented. Elevated $\mathrm{CO}_{2}$ negated the $\mathrm{N}$-induced increase of $\mathrm{AOB}$ observed under ambient $\mathrm{CO}_{2}$, yet caused an increase of $\mathrm{AOA}$ under native soil $\mathrm{N}$ conditions, a response not observed under ambient $\mathrm{CO}_{2}$ condition. Though a positive effect of elevated $\mathrm{CO}_{2}$ on the net nitrification and potential denitrification was observed under the open top chambers fumigation system at a Scot pine seedlings stand forest (Carnol et al., 2002), in comparison with ambient $\mathrm{CO}_{2}$ condition, carbon dioxide enrichment did not significantly increase the abundance of $A O B$ in this study, perhaps due to the relative high level of $\mathrm{NH}_{4}^{+}-\mathrm{N}$ determined in the soils (185 and $191 \mu \mathrm{g} \mathrm{g}^{-1}$ for AU and EU, respectively, Table 1 ). However, elevated $\mathrm{CO}_{2}$ did offset the effects of $\mathrm{N}$ fertilization on the abundance of $\mathrm{AOB}$, suggesting a resource competition. The $\mathrm{N}$ fertilization increased the abundance of $\mathrm{AOB}$ under ambient $\mathrm{CO}_{2}$ due to the increased availability of $\mathrm{NH}_{4}^{+}-\mathrm{N}$, which in consistent with previous findings that higher ammonium concentration promoted the growth of AOB (Okano et al., 2004). Quantitative PCR data of archaeal amoA genes under elevated $\mathrm{CO}_{2}$ condition (i.e., EU, Fig. 1b) are qualitatively consistent with the findings of Lesaulnier et al. (2008). They reported the abundance of two specific dominant OTUs of Crenarchaeota increased significantly under elevated $\mathrm{CO}_{2}$. As in the above description, elevated $\mathrm{CO}_{2}$ increased root exudation and rhizodeposition, which would increase the availability of labile organic carbon. Evidence had demonstrated that the labile organic carbon rather than ammonia availability presented a positive effect on the growth of AOA (Stopnisek et al., 2010). However, a negative linear relationship between the $\delta{ }^{13} \mathrm{C}$ and archaeal amoA gene indicated a positive effect of elevated $\mathrm{CO}_{2}$ on the growth of AOA (Table 2). Under elevated $\mathrm{CO}_{2}$ and $\mathrm{N}$ fertilization, the competition for resources (nutrients and carbohydrates) is greater among different groups of soil microorganisms. It has been reported that fast-growing (r-selected) microorganisms grew better and dominated in response to elevated atmospheric $\mathrm{CO}_{2}$ than the slow-growing (k-selected) microbes such as Nitrosospira or Nitrosospira-like bacteria (Dorodnikov et al., 2009). Therefore, it is likely that AOB could not compete well with other microbes in soil under elevated $\mathrm{CO}_{2}$ and $\mathrm{N}$ fertilization, and thus showed no significant growth response to these conditions. Increased abundance of AOA under elevated $\mathrm{CO}_{2}$ may be related to the potential ability of AOA to utilize both inorganic and organic material as $C$ sources (Hallam et al., 2006; Zhang et al., 2010). However, the effect of elevated $\mathrm{CO}_{2}$ on the abundance of AOA was mitigated by $\mathrm{N}$ fertilization. This, again, may relate to intensified resource competition under both elevated $\mathrm{CO}_{2}$ and $\mathrm{N}$ fertilization as discussed above. Previous studies have demonstrated that different AOB species possess multiple amoA gene copy numbers but

Table 3

Fragment patterns of $a m o A$ genes and distribution of sequence types affiliated with amoA clusters in the clone libraries (\%).

\begin{tabular}{|c|c|c|c|c|c|c|c|c|c|c|}
\hline \multirow[t]{2}{*}{ Treatment } & \multicolumn{3}{|l|}{$\mathrm{AOA}$} & \multicolumn{7}{|l|}{ AOB } \\
\hline & Pattern Number ${ }^{\mathrm{a}}$ & Soil cluster $2^{\mathrm{b}}$ & Soil cluster 5 & Pattern Number & Cluster 1 & Cluster 2 & Cluster 4 & Cluster 9 & Cluster 11 & Cluster 3a \\
\hline $\mathrm{AU}$ & 9 & $22.0 \%$ & $78.0 \%$ & 4 & $4.5 \%$ & $70.8 \%$ & 0 & $24.7 \%$ & 0 & 0 \\
\hline AN & 7 & $13.3 \%$ & $86.7 \%$ & 4 & $18.7 \%$ & $55.8 \%$ & $13.3 \%$ & $12.2 \%$ & 0 & 0 \\
\hline EU & 9 & $25.7 \%$ & $74.3 \%$ & 5 & $13.9 \%$ & $33.8 \%$ & 0 & $31.2 \%$ & $19.8 \%$ & $1.3 \%$ \\
\hline EN & 8 & $21.2 \%$ & $78.8 \%$ & 4 & $19.2 \%$ & $55.9 \%$ & 0 & $19.8 \%$ & $4.3 \%$ & $0.9 \%$ \\
\hline
\end{tabular}

a Pattern numbers are numbers of molecular fragments following digestion with HaelII and Mbol.

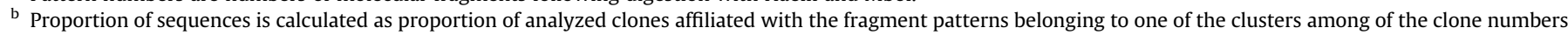
used in the digestion analysis in one clone library. 

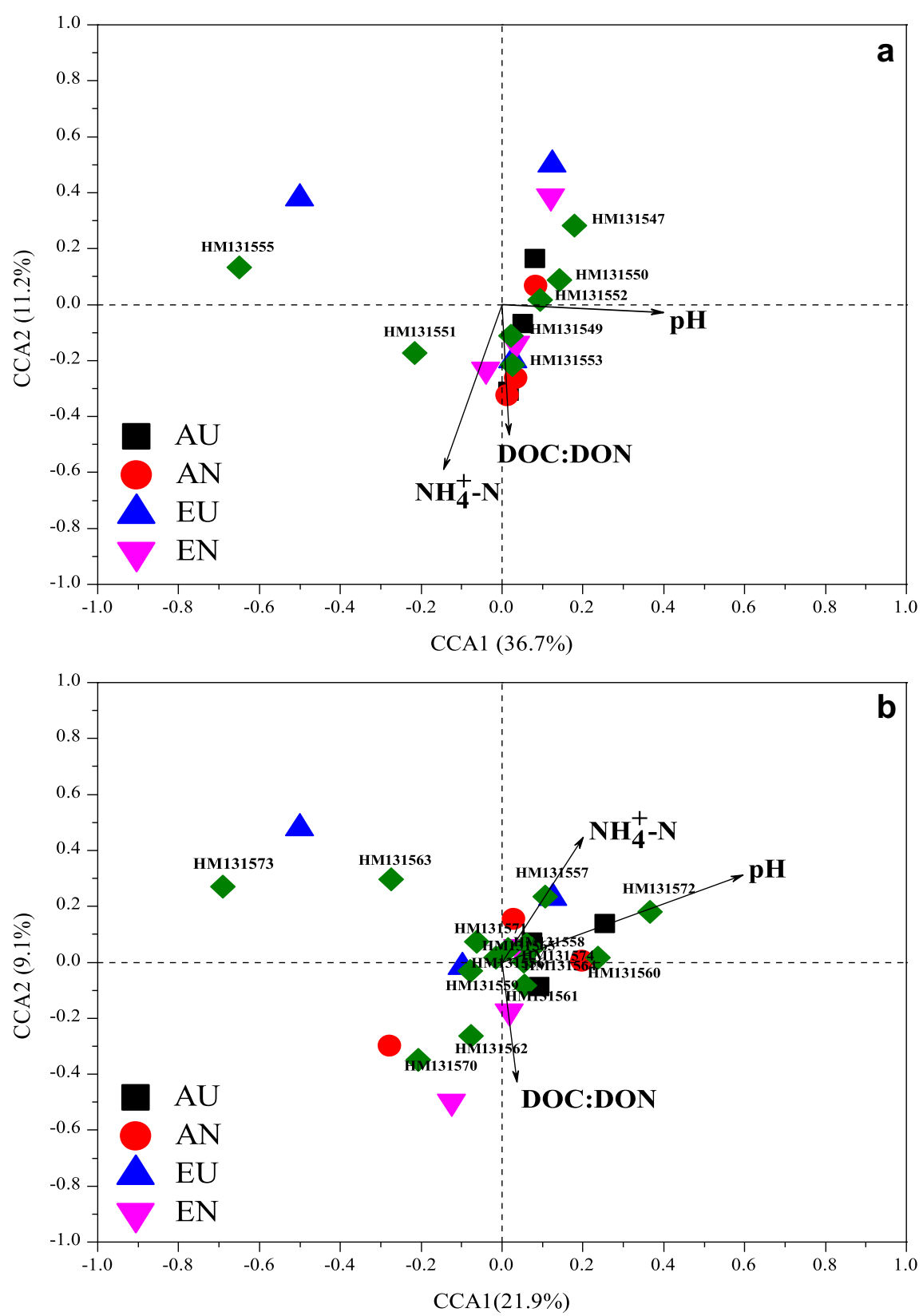

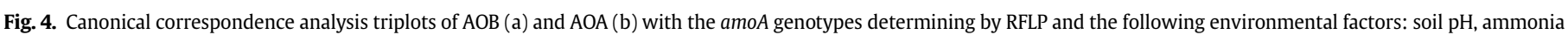
$\left(\mathrm{NH}_{4}^{+}\right)$, and DOC/DON ratio.

only one 16S rRNA gene per cell (Klotz and Norton, 1998; Norton et al., 1996). However, AOA species are considered to hold one copy of the 16S rRNA gene and equal number of the amoA gene (Leininger et al., 2006; Norton et al., 1996). Since amoA gene copy

Table 4

Arlequin AMOVA analyses of amoA gene sequences of Duke FACE soils by RFLP genotype frequencies.

\begin{tabular}{llccll}
\hline & Source of variation & $\begin{array}{l}\text { Variance } \\
\text { components }\end{array}$ & $\begin{array}{l}\text { \% of } \\
\text { variation }\end{array}$ & F-statistics & $p$ \\
\hline AOA & Among treatments & $0.025 \mathrm{Va}$ & 0.59 & $F_{\mathrm{CT}}<0.01$ & $0.31 \pm 0.02$ \\
& Replicates/treatment & $0.130 \mathrm{Vb}$ & 3.10 & $F_{\mathrm{SC}}=0.03$ & $0.00 \pm 0.00$ \\
& Among all samples & $4.033 \mathrm{Vc}$ & 96.31 & $F_{\mathrm{ST}}=0.04$ & $0.00 \pm 0.00$ \\
AOB & Among treatments & $-0.013 \mathrm{Va}$ & -4.10 & $F_{\mathrm{CT}}=-0.04$ & $0.72 \pm 0.01$ \\
& Replicates/treatment & $0.140 \mathrm{Vb}$ & 42.94 & $F_{\mathrm{SC}}=0.41$ & $0.00 \pm 0.00$ \\
& Among all samples & $0.199 \mathrm{Vc}$ & 61.17 & $F_{\mathrm{ST}}=0.39$ & $0.00 \pm 0.00$ \\
\hline
\end{tabular}

number was not directly linked with the activity of the ammonia oxidizers, it did not directly reflect nitrification activity of the ammonia oxidizers.

\subsection{Responses of $A O B$ and $A O A$ community structure to elevated $\mathrm{CO}_{2}$ and $\mathrm{N}$ fertilization}

CCA results revealed that soil niche properties significantly influenced the amoA genotype distribution of $\mathrm{AOB}$ and $\mathrm{AOA}$ rather than elevated $\mathrm{CO}_{2}(p>0.1)$ or $\mathrm{N}$ fertilization $(p>0.1)$. Previous study of this site already showed that the spatial difference rather than elevated $\mathrm{CO}_{2}$ shaped the distribution of bacterial community (Ge et al., 2010). A study on the response of AOB and AOA in the rhizosphere of maize and soybean to elevated $\mathrm{CO}_{2}$ showed no significant difference among treatments based on unweighted PCA of the amoA gene sequences (Nelson et al., 2010). In this study, 
phylogenetic analyses of bacterial amoA genes showed that Nitrosospira or Nitrosospira-like species dominated in all the treatments. Nitrosospira cluster 2 was predominant among the treatments (Fig. 2), which is in agreement with previous studies in which Nitrosospira cluster 2 sequences were found as the most common in acidic soils (Nugroho et al., 2005). The CCA plot indicated that a positive relationship between three bacterial amo $A$ genotypes (HM131547, HM131550, HM131552) and $\mathrm{pH}$ value, showing that these genotypes may be related to a niche of acidic environment. The amoA genotype HM131549 (Nitrosospira cluster 2) and HM131553 (Nitrosospira cluster 4) appeared to link with a niche of high levels of DOC/DON ratio and $\mathrm{NH}_{4}^{+}-\mathrm{N}$. The amoA genotype HM131547 (Nitrosospira cluster 9) was negatively related to the level of $\mathrm{NH}_{4}^{+}-\mathrm{N}$, which is consistent with the previous findings that the Nitrosospira cluster 9 is present at the niche of low level of $\mathrm{NH}_{4}^{+}-\mathrm{N}$ (Avrahami et al., 2003). Moreover, AMOVA of the bacterial amoA genotypes indicated that $42.9 \%$ (Table 4.) of the total variation occurred within the replicates, suggesting that the soil physical-chemical properties dominate the AOB distribution.

In contrast, no remarkable changes in community composition of AOA have been observed in the results of CCA and AMOVA. No significant phylogenetic changes among the treatments confirmed the above CCA and AMOVA results of archaeal amoA genotypes' composition. However, results of CCA in this study showed that only soil pH significantly influenced the composition of archaeal amoA genotype, which is consistent with the prior studies (He et al., 2007; Nicol et al., 2008).

Elevated $\mathrm{CO}_{2}$ and $\mathrm{N}$ fertilization did not affect the community structure of $\mathrm{AOB}$ and $\mathrm{AOA}$, indicating that both ammonia oxidizers had great ecophysiological diversity and as a marker, amoA genes were less significant than 16S rRNA genes in specific niche (Nelson et al., 2010). In this study, community structures of AOB and AOA were not influenced by $\mathrm{N}$ fertilization for only two-year $\mathrm{N}$ addition before the soils sampling.

\section{Conclusion}

This study partly demonstrated that $\mathrm{AOB}$ and $\mathrm{AOA}$ responded differently to elevated $\mathrm{CO}_{2}$ and $\mathrm{N}$ fertilization, based on the abundance of $a m o A$ genes, and that there were significant interactions of multiple factors (e.g., elevated $\mathrm{CO}_{2}$ and $\mathrm{N}$ fertilization) on both ammonia oxidizers, though their community structure did not significant shift with elevated $\mathrm{CO}_{2}$ or $\mathrm{N}$ fertilization. These different responses may be attributed to the shifts in resource availability induced by the elevated $\mathrm{CO}_{2}$ and $\mathrm{N}$ fertilization and to different characteristics of growth and resource competition of different ammonia oxidizer groups. The interactive effects of multiple environmental factors on these organisms frustrate the understanding of the mechanisms responsible for the responses of soil ammonia-oxidizing communities to the shifts in environmental factors. As ammonia oxidizers regulate the rate-limiting step in the $\mathrm{N}$ cycling of highly complex terrestrial ecosystems, the shifts in the abundance and community structure of soil AOA and AOB may have large effect on the $\mathrm{N}$ cycling in forest ecosystems, particularly in a world with continuously rising atmospheric $\mathrm{CO}_{2}$ and $\mathrm{N}$ deposition. Our results imply that AOA may continue to dominate the soil nitrifying processes in this forest ecosystem because the atmospheric $\mathrm{CO}_{2}$ could continue rising in the future. If, however, atmospheric $\mathrm{N}$ deposition would increase, or in stands receiving $\mathrm{N}$ fertilization, AOB may become similarly or of greater importance to ecosystem $\mathrm{N}$ cycling, possibly leading to the acceleration of soil nitrification. Further studies on the potential nitrification rate and amoA gene expression could offer more detailed information of the response of ammonia oxidizers to global change, like elevated $\mathrm{CO}_{2}$, soil warming and $\mathrm{N}$ deposition.

\section{Acknowledgements}

This research was jointly supported by the Australian Research Council, the Chinese Academy of Sciences and the Natural Science Foundation of China. The Duke FACE research was supported by the Office of Science (BER), U. S. Department of Energy, through its FACE facilities program. The authors thank Jeffrey S Pippen and other staffs at DukeUniversity for their assistances in soil sampling.

\section{References}

Avrahami, S., Liesack, W., Conrad, R., 2003. Effects of temperature and fertilizer on activity and community structure of soil ammonia oxidizers. Environmental Microbiology 5, 691-705.

Barnard, R., Barthes, L., Le Roux, X., Harmens, H., Raschi, A., Soussana, J.F. Winkler, B., Leadley, P.W., 2004. Atmospheric $\mathrm{CO}_{2}$ elevation has little effect on nitrifying and denitrifying enzyme activity in four European grasslands. Global Change Biology 10, 488-497.

Bernhard, A.E., Landry, Z.C., Blevins, A., de la Torre, J.R., Giblin, A.E., Stahl, D.A., 2010 Abundance of ammonia-oxidizing archaea and bacteria along an estuarine salinity gradient in relation to potential nitrification rates. Applied and Environmental Microbiology 76, 1285-1289.

Carnol, M., Hogenboom, L., Jach, M.E., Remacle, J., Ceulemans, R., 2002. Elevated atmospheric $\mathrm{CO}_{2}$ in open top chambers increases net nitrification and potential denitrification. Global Change Biology 8, 590-598.

Di, H.J., Cameron, K.C., Shen, J.P., Winefield, C.S., O’Callaghan, M., Bowatte, S., He, J.Z. 2009. Nitrification driven by bacteria and not archaea in nitrogen-rich grassland soils. Nature Geoscience 2, 621-624.

Dorodnikov, M., Blagodatskaya, E., Blagodatsky, S., Fangmeier, A., Kuzyakov, Y., 2009. Stimulation of r-vs. K-selected microorganisms by elevated atmospheric $\mathrm{CO}_{2}$ depends on soil aggregate size. FEMS Microbiology Ecology 69, 43-52.

Drigo, B., van Veen, J.A., Kowalchuk, G.A., 2009. Specific rhizosphere bacterial and fungal groups respond differently to elevated atmospheric $\mathrm{CO}_{2}$. The ISME Journal 3, 1204-1217.

Excoffier, L., Lischer, H.E.L., 2010. Arlequin suite ver 3.5: a new series of programs to perform population genetics analyses under Linux and Windows. Molecular Ecology Resources 10, 564-567.

Feng, X., Simpson, A.J., Schlesinger, W.H., Simpson, M.J., 2010. Altered microbial community structure and organic matter composition under elevated $\mathrm{CO}_{2}$ and $\mathrm{N}$ fertilization in the Duke forest. Global Change Biology 16, 2104-2116.

Finzi, A., Moore, D., DeLucia, E., Lichter, J., Hofmockel, K., Jackson, R., Kim, H., Matamala, R., McCarthy, H., Oren, R., 2006. Progressive nitrogen limitation of ecosystem processes under elevated $\mathrm{CO}_{2}$ in a warm-temperate forest. Ecology 87, 15-25.

Fuhrman, J.A., 2009. Microbial community structure and its functional implications. Nature 459, 193-199.

Ge, Y., Chen, C.R., Xu, Z.H., Oren, R., He, J.Z., 2010. Spatial factor rather than elevated $\mathrm{CO}_{2}$ controls soil bacterial community in a temperate forest ecosystem. Applied and Environmental Microbiology 76, 7429-7436.

Hallam, S.J., Mincer, T.J., Schleper, C., Preston, C.M., Roberts, K., Richardson, P.M., DeLong, E.F., 2006. Pathways of carbon assimilation and ammonia oxidation suggested by environmental genomic analyses of marine Crenarchaeota. PLoS Biology 4, 520-536.

Hallin, S., Jones, C.M., Schloter, M., Philippot, L., 2009. Relationship between $\mathrm{N}$-cycling communities and ecosystem functioning in a 50 -year-old fertilization experiment. The ISME Journal 3, 597-605.

He, J.Z., Xu, Z.H., Hughes, J., 2005. Pre-lysis washing improves DNA extraction from a forest soil. Soil Biology and Biochemistry 37, 2337-2341.

He, J.Z., Xu, Z.H., Hughes, J., 2006. Molecular bacterial diversity of a forest soil under residue management regimes in subtropical Australia. FEMS Microbiology Ecology 55, 38-47.

He, J.Z., Shen, J.P., Zhang, L.M., Zhu, Y.G., Zheng, Y.M., Xu, M.G., Di, H.J., 2007. Quantitative analyses of the abundance and composition of ammoniaoxidizing bacteria and ammonia-oxidizing archaea of a Chinese upland red soil under long-term fertilization practices. Environmental Microbiology 9, 2364-2374.

Heimann, M., Reichstein, M., 2008. Terrestrial ecosystem carbon dynamics and climate feedbacks. Nature 451, 289-292.

Horz, H.P., Barbrook, A., Field, C.B., Bohannan, B.J., 2004. Ammonia-oxidizing bacteria respond to multifactorial global change. Proceedings of the National Academy of Sciences, USA 101, 15136-15141.

Hungate, B.A., Holland, E.A., Jackson, R.B., Chapin Iii, F.S., Mooney, H.A., Field, C.B., 1997. The fate of carbon in grasslands under carbon dioxide enrichment. Nature 388, 576-579.

Hungate, B.A., Dijkstra, P.L., Johnson, D.E.W., Hinkle, C.R.S., Drake, B.T.G., 1999 Elevated $\mathrm{CO} 2$ increases nitrogen fixation and decreases soil nitrogen mineralization in Florida scrub oak. Global Change Biology 5, 781-789.

Jackson, R.B., Cook, C.W., Pippen, J.S., Palmer, S.M., 2009. Increased belowground biomass and soil $\mathrm{CO}_{2}$ fluxes after a decade of carbon dioxide enrichment in a warm-temperate forest. Ecology 90, 3352-3366. 
Klotz, M.G., Norton, J.M., 1998. Multiple copies of ammonia monooxygenase (amo) operons have evolved under biased AT/GC mutational pressure in ammonia oxidizing autotrophic bacteria. FEMS Microbiology Letters 168, 303-311.

Kumar, S., Nei, M., Dudley, J., Tamura, K., 2008. MEGA: a biologist-centric software for evolutionary analysis of DNA and protein sequences. Briefings in Bioinformatics 9, 299-306.

Leininger, S., Urich, T., Schloter, M., Schwark, L., Qi, J., Nicol, G.W., Prosser, J.I., Schuster, S.C., Schleper, C., 2006. Archaea predominate among ammoniaoxidizing prokaryotes in soils. Nature 442, 806-809.

Lesaulnier, C., Papamichail, D., McCorkle, S., Ollivier, B., Skiena, S., Taghavi, S., Zak, D., van der Lelie, D., 2008. Elevated atmospheric $\mathrm{CO}_{2}$ affects soil microbia diversity associated with trembling aspen. Environmental Microbiology 10, 926-941.

Luo, Y., Zhou, X., 2006. Separation of source components of soil respiration. In: Soil Respiration and the Environment. Elsevier Inc., pp. 187-214.

Nelson, D.M., Cann, I.K.O., Mackie, R.I., 2010. Response of archaeal communities in the rhizosphere of maize and soybean to elevated atmospheric $\mathrm{CO}_{2}$ concentrations. PLoS ONE 5 e15897.

Nicol, G.W., Schleper, C., 2006. Ammonia-oxidising Crenarchaeota: important players in the nitrogen cycle? Trends in Microbiology 14, 207-212.

Nicol, G.W., Leininger, S., Schleper, C., Prosser, J.I., 2008. The influence of soil pH on the diversity, abundance and transcriptional activity of ammonia oxidizing archaea and bacteria. Environmental Microbiology 10, 2966-2978.

Norton, J.M., Low, J.M., Klotz, M.G., 1996. The gene encoding ammonia monooxygenase subunit A exists in three nearly identical copies in Nitrosospira sp. NpAV. FEMS Microbiology Letters 139, 181-188.

Nugroho, R.A., R ling, W.F.M., Laverman, A.M., Zoomer, H.R., Verhoef, H.A., 2005 Presence of Nitrosospira cluster 2 bacteria corresponds to $\mathrm{N}$ transformation rates in nine acid Scots pine forest soils. FEMS Microbiology Ecology 53, $473-481$.

O’Neill, E.G., Luxmoore, R.J., Norby, R.J., 1987. Elevated atmospheric $\mathrm{CO}_{2}$ effects on seedling growth, nutrient uptake, and rhizosphere bacterial populations of Liriodendron tulipifera L. Plant and Soil 104, 3-11.

Okano, Y., Hristova, K.R., Leutenegger, C.M., Jackson, L.E., Denison, R.F., Gebreyesus, B., Lebauer, D., Scow, K.M., 2004. Application of real-time PCR to study effects of ammonium on population size of ammonia-oxidizing bacteria in soil. Applied and Environmental Microbiology 70, 1008-1016.

Oksanen, J., Blanchet, G., Kindt, R., Legendre, P., O’Hara, R.G., Simpson, G.L., Solymos, P., Stevens, M.H.H., Wagner, H., 2010. Vegan: Community Ecology Package. R package version $1.17-1$.

Oppermann, B.I., Michaelis, W., Blumenberg, M., Frerichs, J., Schulz, H.M., Schippers, A., Beaubien, S.E., Krüger, M., 2010. Soil microbial community changes as a result of long-term exposure to a natural $\mathrm{CO}_{2}$ vent. Geochimica et Cosmochimica Acta 74, 2697-2716.

Oren, R., Ellsworth, D.S., Johnsen, K.H., Phillips, N., Ewers, B.E., Maier, C., Schafer, K.V.R., McCarthy, H., Hendrey, G., McNulty, S.G., Katul, G.G., 2001. Soil fertility limits carbon sequestration by forest ecosystems in a $\mathrm{CO}_{2}$-enriched atmosphere. Nature 411, 469-472.

Palmroth, S., Oren, R., McCarthy, H., Johnsen, K., Finzi, A., Butnor, J., Ryan, M., Schlesinger, W., 2006. Aboveground sink strength in forests controls the allocation of carbon below ground and its $\left[\mathrm{CO}_{2}\right]$-induced enhancement. Proceedings of the National Academy of Sciences, USA 103, 19362-19367.

Phillips, D.A., Fox, T.C., Six, J., 2006. Root exudation (net efflux of amino acids) may increase rhizodeposition under elevated $\mathrm{CO}_{2}$. Global Change Biology 12 , 561-567.

Rosenzweig, C., Casassa, G., Karoly, D., Imeson, A., Liu, C., Menzel, A., Rawlins, S., Root, T., Seguin, B., Tryjanowski, P., 2007. Assessment of observed changes and responses in natural and managed systems. Climate Change 2007: Impacts, Adaptation and Vulnerability. Contribution of Working Group II to the Fourth Assessment Report of the Intergovernmental Panel on Climate Change, pp. 79-131.

Schaeffer, S.M., Billings, S.A., Dave, E., 2007. Laboratory incubations reveal potential responses of soil nitrogen cycling to changes in soil $\mathrm{C}$ and $\mathrm{N}$ availability in Mojave Desert soils exposed to elevated atmospheric $\mathrm{CO}_{2}$. Global Change Biology 13, 854-865.

Schortemeyer, M., Hartwig, U.A., Hendrey, G.R., Sadowsky, M.J., 1996. Microbial community changes in the rhizospheres of white clover and perennial ryegrass exposed to free air carbon dioxide enrichment (FACE). Soil Biology and Biochemistry 28, 1717-1724.

Shen, J.P., Zhang, L.M., Guo, J.F., Ray, J.L., He, J.Z., 2010. Impact of long-term fertilization practices on the abundance and composition of soil bacterial communities in Northeast China. Applied Soil Ecology 46, 119-124.

Stopnisek, N., Gubry-Rangin, C., Hofferle, S., Nicol, G.W., Mandic-Mulec, I., Prosser, J.I., 2010. Thaumarchaeal ammonia oxidation in an acidic forest peat soil is not influenced by ammonium amendment. Applied and Environmental Microbiology 76, 7626-7633.

Sun, Y., Xing, W., Li, J., Lu, Y., Zuo, J., 2009. Microbial community in granules from a high-rate EGSB reactor. Applied Biochemistry and Microbiology 45, 593-598.

Tourna, M., Freitag, T., Nicol, G., Prosser, J., 2008. Growth, activity and temperature responses of ammonia-oxidizing archaea and bacteria in soil microcosms. Environmental Microbiology 10, 1357-1364.

Wallenstein, M.D., McNulty, S., Fernandez, I.J., Boggs, J., Schlesinger, W.H., 2006. Nitrogen fertilization decreases forest soil fungal and bacterial biomass in three long-term experiments. Forest Ecology and Management 222, 459-468.

Wessén, E., Hallin, S., Philippot, L., 2010. Differential responses of bacterial and archaeal groups at high taxonomical ranks to soil management. Soil Biology and Biochemistry.

Zak, D.R., Pregitzer, K.S., King, J.S., Holmes, W.E., 2000. Elevated atmospheric $\mathrm{CO}_{2}$, fine roots and the response of soil microorganisms: a review and hypothesis. New Phytologist 147, 201-222.

Zhang, L.M., Offre, P.R., He, J.Z., Verhamme, D.T., Nicol, G.W., Prosser, J.I., 2010. Autotrophic ammonia oxidation by soil thaumarchaea. Proceedings of the National Academy of Sciences, USA 107, 17240-17245. 